\title{
A META-REVIEW OF MANAGEMENT INSIGHTS
}

\author{
NGOC-LONG NGUYEN \\ Industrial University of Ho Chi Minh city \\ nguyenngoclong@iuh.edu.vn
}

\begin{abstract}
Purpose: There are several overlaps in terms of management. Different books and different scientists approach different subsets of management definitions. This research has been carried out:

First, through a series of literature reviews, to capture all aspects of the management term.

Second, to shape a systematic relationship enough supporting the term "management", in a hope that it will provide readers with the most optimal definition of management.

Type of research: This is a meta-review research which investigates the insights of management via a systematically comprehensive review of management literature.

Design/Methodology/Approach: The research is conducted with the whole review of existing theoretical literature on management which has been mostly published in Management Science Journal and carefully selected qualified papers or book chapters from drives of typical stores such as Elsevier, Jstore, and so on.

Findings: Literature review reveals that the management definition should cover both quantitative and qualitative aspects of management. The study has provided a comprehensive model of management and the most complete definition of management ever.

Originality: The research has given the findings of entirely sufficient aspects of management comprising both quantitative and qualitative facets and the mutual or causal relationships of synthesized terms.

Keywords: management, management review, management functions, management model, management definition, prosperity.
\end{abstract}

\section{INTRODUCTION}

Over 66 years, after the meeting of 57 individuals in the evening of December 1, 1953 and decided the birth of the Institute of Management Science (TIMS) at Columbia University, the Journal of Management Science was also established, simultaneously, and considered the leading place in the world since then disseminating knowledge about management, encouraging research on management, and promoting the application of management knowledge in practice [1] . So far, there have been thousands of business schools of management around the world providing academic management theories and applied knowledge to practical business administration. Throughout the history of management science, a lot of management concepts have been formed and universalized globally. The term "management" is very complicated to define sufficiently nevertheless. Different scholars at different angles view and interpret it separately according to their interest disciplines. However, no definition of management is accepted as an universal term and widely used in teaching, learning in business schools as well as in practical applications so far.

Ever since "The Principles of Scientific Management" by F.W. Taylor [2], firstly published in 1911, the concept of management was firstly defined scientifically. Since then, the definition of management has been defined in many different ways, each representing a characteristic aspect of discipline that the scholar pursues. Taylor [2], although considered to be the father for management science, first introduced the concept of prosperity and its relationship to the efficiency but this has not been a perfect concept yet. Fayol [3] was interested in management functions and thought that executives wanted to be effective and high-performing, they had to focus on these functions. Drucker [4] viewed managament as a multifunction management task, including managing people and jobs. Urwick [5] ever aimed to improve through sense disambiguation, clarify the meaning of "management" to turn it into a reliable instrument in all places where the term appeared. Many other scholars such as Clegg and Palmer [6], Townley [7] have also tried to synthesize different definitions with the expectation of giving the most universal definition 
but seeming to fail. There has been no definition covering all components of management so far. Until most recently, Kaehler and Grundei [8] also synthesized most of the definition of management from different scientists and practitioners with the ambition of giving the most complete definition of management, but it seems that it still misses or lacks something, making management definition like the sheer inertia or "a triton among the sea of minnows".

With a qualitative and quantitative approach to each component throughout the chain of management cycles, the author has continued to select, align and unify all the elements of management in a unified concept of management including: Disambiguation, tool, material, and achivement. This study indicates for the first time that management:

- involves stakeholders including individuals, organizations, and countries.

- is a system that includes Disambiguation, Tools, Materials, and Achievement.

- should be counted for both qualitative and quantitative activities.

\section{SYSTEMATICALLY COMPREHENSIVE LITERATURE REVIEW}

Method of information synthesis and analysis, 8-step extension [9] from Colaizzi's method, has been applied in this study to synthesize research and definitions of management.

Most of the scientific articles and books about remarkable management science stream are gathered, analyzed and recorded for the serve of related literature issues. The research author collected articles, speeches and books on academic management of typical scholars in the world since the end of the 19th century to the very updated publications.

Keywords: Principles of management, Management, leadership, administration, management functions, objective of management, effectiveness, effeciency, profit, benefit, prosperity, have been used to search for related content.

Google search engine and google scholar have been used to search for management and leadership textbooks. At the same time, Elsevier, Jstore, Spinger Link, Wiley Library, Taylor \& Francis, Emerald, and Management Science journal of INFORMS PubsOnLine have been used to search for scientific papers, book chapters and knowledge-related documents.

After having books and articles that meet relevant search requirements, the titles, the abstracts, the keywords, and the conclusions have been scanned to make up the fundamenetal blocks of related information, discarding unconnected details. After that, the eight steps of Welch [9] was carefully done to capture and systhesize information.

The most recent study of của Kaehler and Grundei [8] on the definition of management has been thoroughly studied and used as a basic research to guide the source of information and to learn more about the shortcomings that this study and previous studies have been ignored.

Table 1 lists and provides management definitions from which the author looks for the deficiencies of each definition.

Table 1. List of definitions of Management

1. Frederick Winslow Taylor "Management is the art of knowing what you want to do and then seeing that they do it in the best and the cheapest may." [2]

2. Henri Fayol "To manage is to forecast and to plan, to organize, to command, to co-ordinate and to control." [3]

3. Mary Parker Follett "The art of getting things done through people". [10]

4. Ordway Tead (1891 - 1973): "Management is the process and agency which directs and guides the operations of an organization in the realizing of established aims." [11]

5. Association of Mechanical Engineers, U.S.A.: "Management is the art and science of preparing, organizing and directing human efforts applied to control the forces and utilize the materials of nature for the benefit to man." [12]

6. Peterson and Plowman , "Management may be defined as the process by means of which the purpose and objectives of a particular human group are determined, clarified and effectuated" [13] 
7. Peter Drucker "Management is a multi-purpose organ that manages a business and manages managers and manages worker and work" [4]

8. Mary Cushing Niles: "Good management achieves a social objective with the best use of human and material energy and time, and with satisfaction for the participants and the public." [14]

9. Louis Allen, "Management is what a manager does." [15]

10. Ralph, C. Davix: "Management is the function of executive leadership anywhere." [16]

11. Keith and Gubellini: "Management is the force that integrates men and physical plant into an effective operating unit." [17]

12. Ralph C. Davis: "Management is the function of executive leadership anywhere." [16]

13. Terry, "Management is not people; it is an activity like walking, reading, swimming or running. People who perform Management can be designated as members, members of Management or executive leaders."[18]

14. Douglas Murray McGregor (1906 - 1964): Management is an approach of creating an environment within which employees are motivated via authoritative direction and control or integration and self-control, which are called theory $\mathrm{X}$ and theory $\mathrm{Y}$, respectively. [19]

15. Harold Koontz "Management is the art of getting things done through others and with formally organised groups." [20]

16. Koontz and O'Donnel "Management is the creation and maintenance of an internal environment in an enterprise where individuals, working in groups, can perform efficiently and effectively toward the attainment of group goals. It is the art of getting the work done through and with people in formally organized groups". [21]

17. George $\mathbf{R}$ Terry 'Management is a distinct process consisting of planning, organising, actuating and controlling; utilising in each both science and art, and followed in order to accomplish pre-determined objectives."[22]

18. Mc Farland: "Management is defined for conceptual, theoretical and analytical purposes as that process by which managers create, direct, maintain and operate purposive organization through systematic, co-ordinated co-operative human effort." [23]

19. Howard M. Carlisle: "Management is defined as the process by which the elements of a group are integrated, coordinated and/or utilized so as to effectively and efficiently achieve organizational objectives." [24]

20. Donald J. Clough: "Management is the art and science of decision-making and leadership". [25]

21. Randall B. Dunham: "Management can be defined as the process of planning, organizing, directing, and controlling organizational resources (human, financial, physical, and informational) in the pursuit of organizational goals." [26]

22. Aldag: "We will define management as a process of planning, organizing and staffing, directing, and controlling activities in an organization in a systematic way in order to achieve a common goal." [27]

23. Stoner et al: "The process of planning, organizing, leading, and controlling the work of organization members and of using all available organizational resources to reach stated organizational goals." [28]

24. Naylor: "Management is the process of achieving organizational objectives, within a changing environment, by balancing efficiency, effectiveness and equity, obtaining the most from limited resources, and working with and through other people." [29]

25. Malik: "Management is the profession of achieving results or obtaining results." [30] 
26. Schermerhorn Jr.: "Management is the process of planning, organizing, leading, and controlling the use of resources to accomplish performance goals." [31]

27. Certo and Certo: "Management is the process of reaching organizational goals by working with and through people and other organizational resources." [32]

28. G.E. Milward: "Management is the process and the agency through which the execution of policy is planned and supervised." [33]

29. Boddy: "Management is the activity of getting things done with the aid of people and other resources." [34]

30. Montana and Charnov: "Management is working with and through other people to accomplish the objectives of both the organization and its members." [35]

31. Lussier and Kimball: "Management embraces all duties and functions that pertain to the initiation of an enterprise, its financing, the establishment of all major policies, the provision of all necessary equipment, the outlining of the general form of organization under which the enterprise is to operate and the selection of the principal officers." [36]

32. Mintzberg: "Management, to repeat, means getting things done through other people — Whether that be on the people plane (leading and linking) or on the information plane (controlling and communicating)." [37]

33. Kinicki, Williams et al.: "Management is defined as (1) the pursuit of organizational goals efficiently and effectively by (2) integrating the work of people through (3) planning, organizing, leading, and controlling the organization's resources."[38]

34. Griffin: "Management: A set of activities (including planning and decision making, organizing, leading, and controlling) directed at an organization's resources (human, financial, physical, and information), with the aim of achieving organizational goals in an efficient and effective manner." [39]

35. Cole and Kelly: "There is no generally accepted definition of 'management' but we consider it to be coordinated activities (forecasting, planning, organizing, deciding, commanding) to direct and control an organization." [40]

36. Gulati, Mayo et al.: "Management: The act of working with and through a group of people to accomplish a desired goal or objective in an efficient and effective manner." [41]

37. Richard L. Daft "The attainment of organizational goals in an effective and efficient manner through planning, organizing, leading, and controlling organizational resources." [42]

38. Robbins and Coulter: "Management is coordinating work activities so that they are completed efficiently and effectively with and through other people." [43]

39. George Elton Mayo "Management is the study of behaviour of people at work" [44]

40. Kaehler and Grundei "Management is a steering influence on market, production and/or resource operations in an organization and its units that may address both people and non-people issues and is exerted by multiple organizational actors through either anticipatory norm-setting (1/4 constitutive or strategic management) or situational intervention (1/4 operational management) with the aim of achieving the unit's objectives. To manage a unit is synonymous with "directing" or "leading" it." [8]

\section{RESULTS OF THE SYSTEMATICALLY COMPREHENSIVE LITERATURE REVIEW}

\subsection{Prosperity - The achievements of management science}

The verbatim concept of prosperity is mentioned in a book named "The Principles of Scientific Management" of Taylor [2] as "the principal object of management should be to secure the maximum prosperity for the employer, coupled with the maximum prosperity for each employee". Although F.W.Taylor mentioned the term of prosperity many time in his documents, he only considered it as a 
result of employee efficiency in the context of production. In his research, he asserted that the purpose of management is to seek prosperity.

Taylor, apart from being considered the father of management science, is also considered to be the most influential person in this field and also the most both appreciated and criticized by his theory [45-47] and he is also considered to have the most followers [48]. Most Taylor's followers greatly sympathize with his view on maximizing efficiency to achieve optimal prosperity. One of the most famoust scholars, a specially excellent follower of Taylor, is Henry Gantt [1861 - 191949], who created the Gantt diagram - the tool is still very popular and useful in management nowadays, especially in project management field.

Prosperity is considered a very difficult term to define in both the nomal sense and the scientific side [50]. Although it is considered by Taylor and his students to be the purpose of management activities, it seems that Taylor did not provide a comprehensive concept well for this glossary. Firstly, he has been opposed by many scholars that he had focused on productivity so he had considered people like a machine, not caring about their feelings and emotions [45, 46]. Secondly, he did not provide a full concept of prosperity that made everyone understand the prosperity of getting the highest employee income and maximum employer benefit as he presented in his publication.

Third, he also indicated in his research that "Prosperity depends upon so many factors entirely beyond the control of any one set of men, any state, or even any one country, that certain periods will inevitably come when both sides must suffer, more or less" [2, p29]. This proves that prosperity is not only the profit of the businesses, the income of the people or the countries, but also includes many other factors. He aslo presented that: "But from whatever cause this increase in productivity has come, it is to the greater productivity of each individual that the whole country owes its greater prosperity." [2, p141]; and "This means increase in prosperity and diminution in poverty, not only for their men but for the whole community immediately around them" [2, p143]. Thus, prosperity is the goal of both individuals, organizations, countries, and even the global; not just businesses. In addition, the prosperity is considered to be the goal of management (as described in the first part), so the concept of management is an activity that serves both individuals, organizations, and countries, and not just the individual business enterprises like people often think. From the information and data above, the first conclusion is drawn:

C1: The purpose of management is to bring prosperity to individuals, organizations, and nations.

Countries often use GDP to measure the growth of the economy every year. Although this indicator can be measured by accurate numerable data of economies and is widely used, it also reveals many limitations. GDP does not measure the satisfaction level of every citizen when the more satisfied levels created by an increase in technology, services, or entertainment are not overall; cannot access the incomes of individuals and households doing business but do not need to declare tax; not taking into account the values brought about by social and charity activities; and so on. Thus, the GDP is not a sufficient measurement of prosperity [51].

According to Legatum Institute, prosperity is a concept that includes both wealth and well-being [52]. This organization offers 09 indicators to measure the prosperity of a nation including: Economic Quality, Business Environment, Governance, Education, Health, Safety and Security, Personal Freedom, Social Capital, and Natural Environment. Therein, Economic Quality is evaluated by 5 different factors: structural policies, economic satisfaction and expectations, distribution of prosperity, engagement, and production quality and diversity. Business Environment is measured by: access, business exibility, clear and fair regulation, and perceptions of meritocracy and opportunity. Governance is estimated by: effective and accountable government, fair elections and political participation, the rule of law, and the level of a country's democracy. Personal Freedom is the sum of: basic legal rights, individual freedom and social tolerance. Social Capital is calculated by 03 factors: social cohesion and engagement, community and family networks, and political participation and institutional trust. Safety and Security is determined by: national security, personal precariousness, and personal safety. Education is accessed by 04 factors: access to education, quality of education, human capital, and country's human capital stock. The health is an estimation of basic health outcomes, health infrastructure and preventative care, and physical and mental health. Whileas Natural Environment is analized by factor such as physical (e.g. air quality), social (e.g. green areas to meet), and symbolic (e.g. national parks) [53]. 
Factors contributing to the measurement of prosperity above show that many factors can be measured by specific arithmetic but that many factors cannot be accurately measured but can only be estimated by the sensory quantity. Indicators such as GDP, consumer price index, inflation and unemployment rates, and some other indicators can all be determined by a good mathematical quantification. Some indicators like economic satisfaction, expectations, rights, safety and security and many other indicators cannot be accurately measured, but can only be estimated in the most appropriate way to determine the evaluation. In addition, the purpose of understanding the ontology of the term of management and assessing administrative activities or economic behaviors to help managers can make accurate decisions. In order to measure economic factors or management activities, statistic is always an effective tool of choice. Meanwhile, quantitative and qualitative measure gives the best suited results of each economic activity or each management activity to draw the whole view of needed information for managers and leaders [54]. Thus, another conclusion is drawn:

C2: The prosperity should be measured by both a quantitative scale and a qualitative scale.

Many previous studies have shown that GDP is used to measure the volume of products made by a country or the growth of economics [e.g., 50, 52, 55]. The fact is that GNP (Gross National Product) now changed to GNI (Gross National Income) - actually reflects the growth of a nation's assets rather than GDP. Because GDP is the total product made inside the border of a country without discussing the national possession of products it belongs to; GNP or GNI, meanwhile, is the total value generated by the people of a country without regard to the place where the products were created [56]. However, as indicated above, GDP cannot cover all wellbeing values created by a country such as health care, education, culture, entertainment, environment, etc., so GDP only represents quantitative parts and the or countries need to consider other wellbeing qualitative measures. At the lower level of a nation, the organizations also operate only for two purposes: profit and non-profit. In fact, non-profit organizations still seek profit in their activities to finance the fund and activities that they are currently operating. Enterprises operating for profit purposes must still ensure the value of social benefit for owners and employees; for their businesses and for the nearby society [57, 58]. From very early on, scholars were interested in the welfare of workers. Individuals in addition to their income from labor compensation also need welfare values such as training, health, democracy, social insurance, job satisfaction, etc. [45, 59]. From the above reasons, this study draws the following conclusion:

C3: The prosperity of individuals includes Income and Welfare, of organizations includes Profit and Benefit, and of countries includes Growth and Wellbeing.

\subsection{The differences of management and leadership}

Management in previous definitions utilizes different terms such as administration (e.g., business administration faculty, master of business administration...), management (e.g., business management, management science, marketing management...), và leadership (e.g., team leader, leadership). These terms are confused in name and there is no clear distinction to use in reality. Many studies have tried to clarify the differences of these terms, but it seems to be still unclear concepts. [e.g., 60, 61-64]. Most recently, Kaehler and Grundei [8] still suggested that the concept of management is synonymous with leading and "To manage a unit is synonymous with "directing" or "leading" it.".

Because leadership is defined as influencing employees through interpersonal skills. In the book "Leadership: Theory and practice" [65], the authors have defined "Leadership is a process whereby an individual influences a group of individuals to achieve a common goal.". In his book, Kotter [64] poited out the differences between management and leadership as follows:

Table 2: Differences between management and leadership

\begin{tabular}{|c|r|}
\hline $\begin{array}{c}\text { Management } \\
\text { (Produces Order and Consistency) }\end{array}$ & \multicolumn{1}{c|}{$\begin{array}{c}\text { Leadership } \\
\text { (Produces Change and Movement) }\end{array}$} \\
\hline Planning and Budgeting & Establishing Direction \\
& Establish agendas \\
$\bullet \quad$ Set timetables & $\bullet \quad$ Create a vision \\
\hline
\end{tabular}




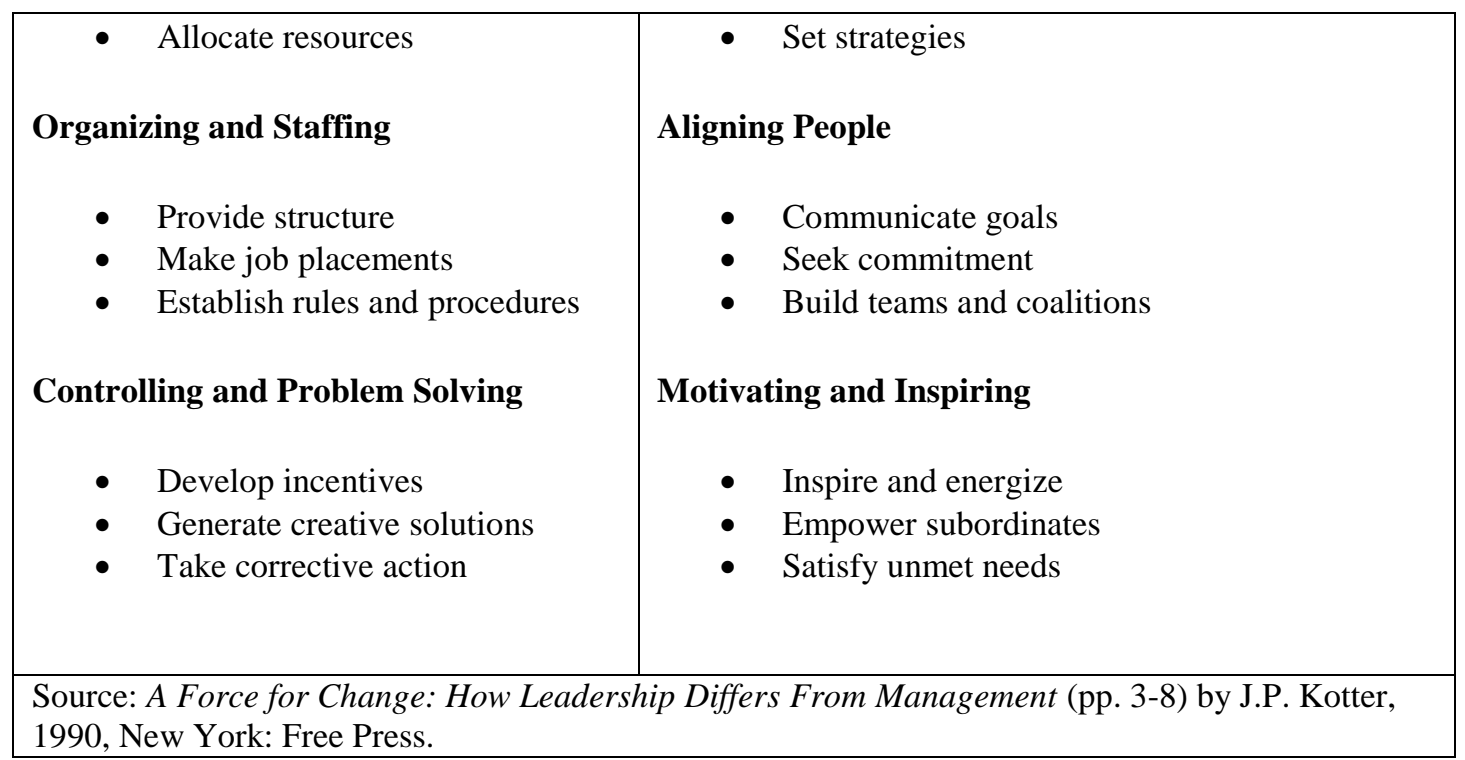

Thereby, the management includes two activities: management and leadership and these two terms are two quite different concepts. Bennis and Nanus [66] stated: "The manager does things right; the leader does the right thing". Management is the task to manage and control subodinates by rules and regulations. It aims to increase the effecient performance or productivity of employees; and defines objectives, targets and ways to reach those objectives and targets for the followers. The objectives, targets and methods to reach the limits of performance through management activities can be measured by quantification easily. Management is both art and science [67] and management is the science facet which has the effect of pushing the employees to follow the objectives and targets, and the completeness of these predetermined requirements. However, cotrolling people by rules is normally criticised as not taking the feeling of subordinates into account. So, management is concluded as:

C4: Management is the activity of managing employees through objectives and quantitative tools in a highly efficient way.

In addition, the leader is considered the creator of vision [64], using his credibility to motivate and influence his subordinates to finish tasks. All of these factors (the influence and motivation skills) are only qualitative, cannot be accurately measured. Leadership impacts and pull employees and people in the organization to the purpose (vision) of the organization, in other words, it aims to result in a highly effective way. The distinction between efficiency and effectiveness was discussed by Lewin and Minton [68], unmistakably: "Effectiveness is the degree to which the organizations achieve the goals, and efficiency is the use of minimal resources to produce desired output". In addition, leadership can be seen as the artistic side of management. Many management schools consider leadership an innate aptitude or an artistic ability [e.g., 69, 70]. Thus, leadership is concluded:

C5: Leadership is an effective way to manage employees through qualitative tools through vision setting and personal influences.

\subsection{The management functions}

Many definitions of previous scientists have a key component of management functions [e.g., 3, 7173]. In this study, we continue to inherit four functions of management as of Jones, et al. [73] including Planning, Organizing, Leading, and Controlling. In particular, leading function is defined as the activity to motivate and influence subodinates [71]. Since then, the fifth conclusion is drawn:

C6: Management includes four functions: Planning, Organization, Leading, and Controllings.

\subsection{Object of management functions - tangible and intangible resources}

Many authors have considered the object of management functions as resources [e.g., 42, 74] and these resources are classified as "people and non-people issues". Resources are inherently limited, so they 
must have been controlled by management functions so that the use of resources is optimal. In other words, the managers have to manage the resources in a highly efficient way. Some previous definitions listed resources as human, physical, and financial resources. In this study, we aim to clarify the qualitative and quantitative aspects of the whole process and components of management so we allocate resources into two parts: Tangible aspect (e.g, land, machines, products, material ...) - numerically measurable part; and Intangsible part (copyright, patent, market reputation ...) - the part that can only be measured by qualitative. Thus, the drawn conclusion is:

C7: Resources are the objective of management functions and consist of two parts: Tangible and Intangible facets.

\subsection{Integarated model and proposed definition}

After summing up all the above conclusions (C1-C7), we find that the management modelling is necessary because it gives a clear and comprehensive image of management, before submitting a quite completed definition of management. The entire management process is modeled as shown in Figure 1.



From the management insight model, we recommend redefining management as follows:

"Management is the activity of management and leadership with the implementation of four functions including planning, organization, leading, and controlling to tangible and intangible resources in the most efficient way to create prosperity with high effectivenss for stakeholders".

\section{CONCLUSION}

Economics plays an important role for every individual, organization, and nation. Management science contributes role significantly to economic growth; personal, organizational and social development. Understanding the fundamental knowledge of management helps teach, study, and apply business knowledge smoothly, especially the knowledge of business administration.

This study synthesizes the core issues of management and builds up a model that fully emulates the concept of management, thereby drawing the most comprehensive definition including all elements in previous definitions. This definition provides a holistic view of management that makes it possible for people with access to generalize all aspects of management and leadership. With the desire to contribute to the formation of a universal definition for a management definition, this research, despite universalizing most of the problems of management, still has some limitations that have not yet been analyzed such as the missing of analysis of relationships, or not quantifying the extent to which the ratio 
between qualitative and quantitative is sufficient to achieve optimal levels of prosperity for individuals, organizations, and countries. It is hoped that future research will continue to deepen our understanding of the comprehensive management model and expand additional knowledge to understand the more comprehensive definition.

\section{REFERENCES}

[1] W. J. J. M. S. Hopp, "Fifty years of management science," vol. 50, no. 1, pp. 1-7, 2004.

[2] F. W. Taylor, The principles of scientific management. Harper, 1914.

[3] H. J. C. o. o. t. Fayol, "General principles of management," vol. 2, no. 15, pp. 57-69, 1916.

[4] P. J. N. Y. Drucker, "The principles of management," 1954.

[5] L. F. J. C. M. R. Urwick, "The problem of management semantics," vol. 2, no. 3, pp. 77-83, 1960.

[6] S. R. Clegg and G. Palmer, The politics of management knowledge. Sage, 1996.

[7] B. J. J. o. M. S. Townley, "Performance appraisal and the emergence of management," vol. 30, no. 2, pp. 221$238,1993$.

[8] B. Kaehler and J. Grundei, "The Concept of Management: In Search of a New Definition," in HR Governance: Springer, 2019, pp. 3-26.

[9] T. Welch, "The extension of Colaizzi's method of phenomenological enquiry AU - Edward, Karen-Leigh," Contemporary Nurse, vol. 39, no. 2, pp. 163-171, 2011/10/01 2011.

[10] M. P. J. B. m. a. a. p. Follett, "Management as a profession," pp. 73-87, 1927.

[11] O. Tead, The art of leadership. Mcgraw-Hill Book Company; New York, 1935.

[12] W. Shewhart, "Potential opportunities for statisticians," 1944.

[13] C. J. P. S. Q. O'Donnell, "The source of managerial authority," vol. 67, no. 4, pp. 573-588, 1952.

[14] M. C. Niles, The essence of management. 1958.

[15] L. A. J. S. i. M.-H. M. Allen, "Management and organization," 1958.

[16] R. C. J. A. o. M. J. Davis, "A philosophy of management," vol. 1, no. 3, pp. 37-40, 1958.

[17] L. A. Keith and C. E. Gubellini, Business management. McGraw-Hill, 1958.

[18] G. R. Terry, "Principles of management . Homewood, IL: Richard D. Irwin," ed: Inc, 1960.

[19] D. MacGregor, The human side of enterprise (no. 166-171). New York McGraw-Hill, 1960.

[20] H. J. A. o. M. j. Koontz, "The management theory jungle," vol. 4, no. 3, pp. 174-188, 1961.

[21] H. Koontz and C. O'Donnell, Principles of management. McGraw-Hill Book Company, 1964.

[22] G. R. Terry and S. G. Franklin, Principles of management. RD Irwin, 1968.

[23] D. E. McFarland, Management: Principles and practices. Macmillan Pub Co, 1974.

[24] H. M. Carlisle, Management: Concepts, methods, and applications. Science Research Associates, 1982.

[25] D. J. Clough, Decisions in public and private sectors: Theories, practices, and processes. Prentice Hall, 1984.

[26] J. L. P. Randall B. Dunham, Management. Glenview, Illinois : Scott, Foresman \& Company, 1989.

[27] R. J. S. Aldag, Timothy M., Management, 2nd ed, ed. College Division, South-Western Pub. Co, Cincinnati, 1991.

[28] J. A. Stoner, R. E. Freeman, D. R. J. U. P.-H. A. Gilbert, Stress, and Coping, " Management," vol. 17, no. 1, pp. 103-122, 1995. 
[29] J. Naylor, Management. Financial Times/ Prentice Hall 1999.

[30] F. J. F. a. M. C. Malik, "Managing performing living: Effective management for a new era (English edition 2006)," 2000.

[31] J. R. Schermerhorn Jr, "Management (eigth edition)," ed: John Wiley \& Sons, New York, 2005.

[32] S. C. Certo and S. T. Certo, Modern management. Pearson/Prentice Hall, 2006.

[33] G. E. Milward, Large Scale Organisation-A First-Hand Account of the Day-To-Day Organisation and Management of Large Industrial Undertakings. Read Books, 2007.

[34] D. Boddy, Management: an introduction. Pearson Education, 2008.

[35] P. J. Montana and B. H. J. I. P. Charnov, "Management. New York. Barron's Educational Series," vol. 333, 2008.

[36] R. N. Lussier and D. C. Kimball, Applied sport management skills. Human Kinetics, 2009.

[37] H. Mintzberg, Managing. Berrett-Koehler Publishers, 2009.

[38] A. Kinicki, B. K. Williams, B. D. Scott-Ladd, and M. Perry, Management: A practical introduction. McGrawHill Irwin, 2011.

[39] R. W. Griffin, Fundamentals of management. Cengage Learning, 2013.

[40] K. Cole and P. Kelly, Management theory and practice. Cengage Learning, 2015.

[41] R. Gulati, A. J. Mayo, and N. Nohria, Management: An integrated approach. Cengage Learning, 2016.

[42] R. L. Daft and D. Marcic, Understanding management. Nelson Education, 2016.

[43] S. P. Robbins and M. J. E. P. E. Coulter, "Management (13th global edition)," 2016.

[44] R. C. Trahair and A. Zaleznik, Elton mayo: The humanist temper. Routledge, 2017.

[45] A. M. Blake and J. L. J. P. I. Moseley, "One hundred years after The Principles of Scientific Management: Frederick Taylor's life and impact on the field of human performance technology," vol. 49, no. 4, pp. 27-34, 2010.

[46] E. A. J. A. o. M. R. Locke, "The ideas of Frederick W. Taylor: an evaluation," vol. 7, no. 1, pp. 14-24, 1982.

[47] D. J. B. H. R. Nelson, "Scientific management, systematic management, and labor, 1880-1915," vol. 48, no. 4, pp. 479-500, 1974.

[48] P. B. Peterson, "THE FOLLOWERS OF HENRY L. GANTT (1861-1919)," in Academy of Management Proceedings, 1993, vol. 1993, no. 1, pp. 174-178: Academy of Management Briarcliff Manor, NY 10510.

[49] M. L. Pinedo, Scheduling: theory, algorithms, and systems. Springer, 2016.

[50] I. Cassiers, Redefining Prosperity. Routledge, 2014.

[51] J. E. Stiglitz, A. Sen, axnd J.-P. J. O. d. h. b. 1. J. A. J. Fitoussi, "Measurement of economic performance and social progress," vol. 26, p. 2012, 2009.

[52] R. Bate, "What Is Prosperity and How Do We Measure It?," 2009.

[53] M. Gligorić, B. J. Gavrilović, and L. J. T. Savić, "PROSPERITY INDEX AS A MEASURE OF WELLBEING IN EUROPEAN UNION AND WESTERN BALKAN COUNTRIES," pp. 1253-1275, 2019.

[54] E. V. Sibirskaya, L. V. Oveshnikova, L. A. Mikheykina, and I. R. Lyapina, "Introduction to Economic Statistics," in Economic Systems Analysis: Statistical Indicators: Springer, 2019, pp. 1-6.

[55] T. Jackson, Prosperity without growth: Economics for a finite planet. Routledge, 2009.

[56] M. P. Todaro and S. C. Smith, "Economic Development, 2011," ed: Addison-Wesley is an Imprint of Pearson, 2011.

[57] J. W. J. J. o. L. R. Budd, "Non-wage forms of compensation," vol. 25, no. 4, pp. 597-622, 2004. 
[58] M. J. s. b. Kelly, "Not just for profit," vol. 54, pp. 1-10, 2009.

[59] K. E. J. T. R. o. E. S. Boulding, "Income or welfare," vol. 17, no. 2, pp. 77-86, 1949.

[60] G. Yukl, "Managerial Leadership: A Review of Theory and Research," vol. 15, no. 2, pp. 251-289, 1989.

[61] L. Kolber and L. I. MacDonald, "Management and Leadership in Business," in Leo(A Life: McGill-Queen's University Press, 2003, pp. 242-259.

[62] J. J. T. J. f. Q. Kotterman and Participation, "Leadership versus management: what's the difference?," vol. 29, no. 2, p. 13, 2006.

[63] L. Smircich and G. J. T. J. o. a. b. s. Morgan, "Leadership: The management of meaning," vol. 18, no. 3, pp. 257-273, 1982.

[64] J. P. J. N. Y. F. P. Kotter, "How leadership differs from management," vol. 240, pp. 59-68, 1990.

[65] P. G. Northouse, Leadership: Theory and practice. Sage publications, 2018.

[66] W. N. Bennis and A. Nanus, "Leaders, The Strategies for Taking Charge," ed: Harper \& Row Publishers, 1985.

[67] E. Bradley, Reliability Engineering: A Life Cycle Approach. CRC Press, 2016.

[68] A. Y. Lewin and J. W. J. M. s. Minton, "Determining organizational effectiveness: Another look, and an agenda for research," vol. 32, no. 5, pp. 514-538, 1986.

[69] C. L. J. N. S. Giltinane, "Leadership styles and theories," vol. 27, no. 41, 2013.

[70] S. Reicher, N. J. L. Hopkins, p. I. p. i. groups, and organizations, "15 On the Science of the Art of Leadership," p. $197,2003$.

[71] K. M. Bartol and D. C. J. N. Y. Martin, NY, "Management (3rd)," 1998.

[72] G. A. Cole and P. Kelly, Management theory and practice. Cengage Learning, 2015.

[73] G. R. Jones, J. M. George, and C. W. Hill, Contemporary management. Irwin/McGraw-Hill, 2018.

[74] J. L. Pierce, D. G. Gardner, L. L. Cummings, and R. B. J. A. o. M. j. Dunham, "Organization-based selfesteem: Construct definition, measurement, and validation," vol. 32, no. 3, pp. 622-648, 1989.

Received on February ${ }^{\text {st }}$, 2019

Accepted on March 25 $5^{\text {th }}, 2019$ 